\title{
Perbedaan hasil belajar dasar desain grafis dengan menerapkan model pembelajaran CBL (Challenge Based Learning) berbantuan animasi dibandingkan model pembelajaran CBL berbantuan web pada siswa kelas $X$ di SMK Islam Batu
}

\author{
Ahmad Lutfi Hidayatulloh', Tri Atmadji Sutikno², I Made Wirawan ${ }^{3}$ \\ 1. Universitas Negeri Malang, Indonesia | hidayama.hidayatulloh@gmail.com \\ 2. Universitas Negeri Malang, Indonesia | tri.atmadji.ft@um.ac.id \\ 3. Universitas Negeri Malang, Indonesia | made.wirawan.ft@um.ac.id
}

\begin{abstract}
Abstrak
Penelitian ini mengungkapkan perberbedaan hasil belajar dasar desain grafis dengan menerapkan model pembelajaran CBL (Challenge Based Learning) berbantuan animasi dibandingkan model pembelajaran CBL berbantuan web pada siswa kelas $X$ di SMK Islam Batu. Penelitian ini menggunakan racangan eksperimen semu dengan bentuk Non-Equivalent Control Group Design. Sampel penelitian yaitu 22 siswa sebagai kelas eksperimen diberi perlakuan penerapan model pembelajaran CBL berbantuan animasi dan 17 siswa diberi perlakuan penerapan model pembelajaran CBL berbantuan web. Pengukuran dalam penelitian ini menggunakan tes dalam ranah kognitif dan psikomotorik. Dalam uji hipotesis pada penelitian ini menggunakan uji-t dengan taraf signifikansi sebesar 0,05 . Hasil penelitian ini menunjukkan hasil signifikansi sebesar 0,03 untuk ranah kognitif dan 0,04 untuk ranah psikomotorik. Kelas eksperimen mengalami kenaikan sebesar 51,82 di ranah kognitif dan 40,77 di ranah psikomotorik, sedangkan kelas kontrol mengalami kenaikan sebesar 41,41 di ranah kognitif dan 43,40 di ranah psikomotorik. Selisih hasil belajar untuk ranah kognitif dari kedua kelas yaitu sebesar 6,58 dan 6,46 untuk ranah psikomotorik. Berdasarkan hasil yang telah didapatkan, signifikansi yang diperoleh lebih kecil dari 0,05 sehingga dapat disimpulkan bahwa terdapat perbedaan hasil belajar dasar desain grafis dengan menerapkan model pembelajaran $\mathrm{CBL}$ berbantuan animasi dibandingkan model pembelajaran $\mathrm{CBL}$ berbantuan web.
\end{abstract}

\section{Kata Kunci}

Challenge Based Learning, Animasi, Web, Hasil Belajar, Dasar Desain Grafis 


\section{TEKNO Jurnal Teknologi Elektro dan Kejuruan}

http://journal2.um.ac.id/index.php/tekno | ISSN 1693-8739

\section{Pendahuluan}

Pembelajaran desain grafis terbagi menjadi dua yaitu teori dan praktikum, sehingga siswa dituntut untuk menguasai materi dan mampu menerapkannya di saat praktikum. Sayangnya hal ini belum terpenuhi karena selama proses pembelajaran banyak ditemui kesalahan-kesalahan yang sama diantara siswa khususnya saat praktikum.

Kesalahan yang sering muncul adalah anggapan bahwa ketika gambar bitmap di edit menggunakan software pengolah gambar vektor seperti Corel Draw maka gambar tersebut otomatis menjadi gambar vektor. Kesalahan mendasar seperti ini berimbas kepada hasil belajar siswa yang rendah, sehingga perlu dilakukan upaya untuk memahamkan siswa yang mana juga meningkatkan hasil belajar mereka.

Hasil belajar siswa pada hakikatnya merupakan perubahan tingkah laku setelah melalui proses belajar mengajar (Majid, 2015: 28). Tingkah laku sebagai hasil belajar dalam pengertian luas mencakup bidang afektif, kognitif dan psikomotorik, sendangkan dalam pengertian yang lebih sempit khususnya pada penelitian ini yakni hanya mencakup ranah kognitif dan psikomotorik. Ranah kognitif didapat dari pemberian soal diakhir proses pembelajaran, sedangkan ranah kognitif didapat dari pembuatan karya desain, kecepatan mengerjakan dan menilai desain.

Selain kesalahan dasar tersebut, ternyata setelah dilakukan observasi ditemukan hal-hal lain yang mempengaruhi rendahnya nilai siswa yakni minat siswa yang cenderung rendah, pasif dalam pembelajaran, dan kurang motivasi dalam belajar. Hal-hal tersebut dikarenakan media yang digunakan selama ini masih terbatas pada power point sederhana dan tidak termasuk dalam media interaktif, padahal media memiliki peran yang sangat signifikan di dalam pembelajaran.

Media pembelajaran adalah segala sesuatu yang digunakan untuk menyalurkan pesan dari pengirim ke penerima sehingga dapat merangsang pikiran, perasaan, perhatian dan minat serta perhatian siswa sedemikian rupa sehingga terjadi poses belajar (Sadiman, 2010: 7), sedangkan pengertian lain media pembelajaran sebagai sesuatu yang dipergunakan sebagai perantara komunikasi dalam kegiatan pembelajaran (Setyosari, 2005: 18).

Berdasar kedua pendapat tersebut tentu didapati bahwa media memiliki peran penting dan harus dibuat sedemikian rupa sehingga dapat menarik minat siswa dan menjadikan pembelajaran lebih menarik.

Namun sebaik apapun media yang dikembangkan, ketika model pembelajaran yang digunakan tidak tepat atau sesuai dengan siswa maka pembelajaran tetap membosankan. Hal inilah yang juga mendasari pemilihan model pembelajaran CBL (Challenge Based Learning) dalam penelitian ini (Johnson, dkk. 2009). Model ini dipilih karena merupakan pengalaman belajar kolaboratif, dimana pendidik dan siswa bekerja sama mempelajari topik terkini, dan menawarkan solusi nyata bagi permasalahan tersebut, serta bertindak (Yudo, 2014: 11). 


\section{TEKNO Jurnal Teknologi Elektro dan Kejuruan}

http://journal2.um.ac.id/index.php/tekno | ISSN 1693-8739

Penelitian ini bertujuan untuk mengetahui adanya peningkatan hasil belajar dasar desain grafis dengan menerapkan model pembelajaran $\mathrm{CBL}$ berbantuan animasi dan model pembelajaran CBL berbantuan web pada siswa kelas $X$ di SMK Islam Batu. Melalui penelitian ini, secara teoritis dapat bermanfaat bagi seluruh guru dalam hal pengembangan media pembelajaran yang tepat untuk meningkatkan hasil belajar siswa. Selain itu untuk siswa dapat bermanfaat untuk membantu siswa dalam meningkatkan hasil belajar menggunakan media animasi dan web, untuk peneliti, bermanfaat sebagai penambahan wawasan tentang perbedaan serta peningkatan hasil belajar dasar desain grafis dengan menggunakan model pembelajaran CBL berbantuan animasi dan berbantuan web.

\section{Metode}

Penelitian ini bertujuan untuk mengetahui peredaan hasil belajar dasar desain grafis dengan menerapankan model pembelajaran CBL berbantuan animasi dan berbantuan web pada siswa kelas $X$. Dalam penelitian ini, metode eksperimen yang digunakan adalah rancangan eksperimen semu (Quasy-Experimental Design). Rancangan yang digunakan dalam eksperimen ini adalah Pretest-Posttest bentuk Non-Equivalent Control Group Design.

Instrumen penelitian yang digunakan pada penelitian ini terdiri atas instrumen perlakuan dan instrumen pengukuran. Pada instrumen perlakuan terdapat beberapa instrumen yang digunakan, antara lain: (1) silabus, yang digunakan sebagai rancangan pembelajaran yang digunakan sebagai pedoman dalam proses pembelajaran. (2) RPP, yang digunakan sebagai acuan dalam proses pembelajaran pada kompetensi dasar 3.7 dan 4.7 mata pelajaran dasar desain grafis (3) media animasi, sebagai media yang diberikan kepada siswa untuk menunjang pembelajaran pada kelas eksperimen. (4) media web, sebagai media untuk menunjang pembelajaran di kelas kontrol.

Pada instrumen pengukuran terdapat soal pretest sebagai alat pengukuran kemampuan awal siswa dan soal posttest sebagai alat pengukuran kemampuan akhir siswa.

Dalam teknik pengumpulan data, terdapat dua tahapan yaitu tahap persiapan yang terdiri dari: (1) pelaksanaan observasi untuk menemukan permasalahan yang dihadapi, (2) penetapan kelas eksperimen dan kelas kontrol, (3) penyusunan instrumen penelitian, (4) validasi instrumen penelitian. Kemudian tahap berikutnya adalah tahap pelaksanaan yang terdiri dari: (1) melakukan pre-test untuk mengetahui kemampuan awal siswa, (2) melakukan uji normalitas, uji homogenitas, dan uji kesamaan rata-rata (3) implementasi model CBL berbantuan Animasi pada kelas eksperimen dan model CBL berbantuan Web pada kelas kontrol, dan (4) melaksanakan post-test kepada kedua kelas untuk mengetahui hasil belajar dasar desain grafis setelah dilakukan perlakuan.

\section{Hasil}

Pada penelitian ini data yang didapatkan melalui tahapan pengumpulan data yaitu data pretest dan posttest. Data pretest diperoleh sebelum siswa pada masing-masing kelas diberikan 


\section{TEKNO Jurnal Teknologi Elektro dan Kejuruan}

http://journal2.um.ac.id/index.php/tekno | ISSN 1693-8739

perlakuan dalam pembelajaran, sedangkan data posttest diperoleh setelah siswa pada masingmasing kelas diberikan perlakuan. Data hasil perolehan penelitian diolah menggunakan bantuan software SPSS 24.0 for Windows.

Perbandingan perolehan data pretest pada kelas eksperimen dengan jumlah siswa 22 orang dan kelas kontrol dengan jumlah siswa 17 orang yaitu, pada kelas eksperimen diperoleh data awal rata-rata sebesar 35,00 sedangkan pada kelas kontrol diperoleh data awal sebesar 38,83. Sedangkan pada data posttest diperoleh data yaitu, untuk ranah kognitif didapatkan hasil pada kelas eksperimen sebesar 86,82 dan pada kelas kontrol diperoleh data sebesar 80,24, di ranah psikomotorik sendiri, kelas eksperimen memperoleh data sebesar 75,77 sedangkan kelas kontrol mendapatkan data sebesar 82,23. Melalui perolehan data tersebut dapat diambil kesimpulan bahwa terdapat peningkatan antara kelas sebelum diberikan perlakuan dan kelas setelah diberikan perlakuan, baik pada kelas eksperimen maupun pada kelas kontrol.

Sebelum data dilakukan uji hipotesis, terlebih dahulu dilakukan uji prasyarat analisis, pada uji ini dilakukan uji normalitas dan uji homogenitas. Uji dilakukan guna memastikan apakah subjek uji pada kelas eksperimen dan kelas kontrol memiliki distribusi yang normal dan homogen. Data hasil uji prasyarat analisis, normalitas data awal diuraikan sebagai berikut:

1. Pada kelas $X$ MM selaku kelas eksperimen dengan jumlah total subjek uji 22 siswa didapatkan data signifikansi Asymp-Sig sebesar 0,143, yang dapat disimpulkan bahwa data terdistribusi normal, berdasarkan ketetapan jika signifikansi $>\alpha(0,05)$, maka disimpulkan bahwa sampel berasal dari populasi yang terdistribusi normal.

2. Pada kelas $X$ RPL selaku kelas kontrol dengan jumlah total subjek uji 17 siswa didapatkan hasil signifikansi Asymp-Sig sebesar 0,115 yang berarti data terdistribusi normal dengan ketetapan yang sama.

Sedangkan data hasil uji prasyarat analisis normalitas data akhir diuraikan sebagai berikut:

1. Pada kelas eksperimen dengan jumlah total subjek uji 22 siswa didapatkan data signifikansi Asymp-Sig sebesar 0,083 untuk ranah kognitif dan 0,118 untuk ranah psikomotorik, dari kedua data tersebut dapat disimpulkan bahwa data terdistribusi normal, berdasarkan ketetapan jika signifikansi $>\alpha(0,05)$, maka disimpulkan bahwa sampel berasal dari populasi yang terdistribusi normal.

2. Pada kelas kontrol dengan jumlah total subjek uji 17 siswa didapatkan hasil normalisasi dengan signifikansi Asymp-Sig sebesar 0,161 untuk ranah kognitif dan 0,186 untuk ranah psikomotorik, yang mana berarti data terdistribusi normal.

Data hasil uji prasyarat analisis, homogenitas kemampuan awal dan kemampuan akhir diuraikan sebagai berikut:

1. Hasil uji homogenitas kemampuan awal kelas eksperimen dan kelas kontrol didapatkan hasil signifikansi Asymp-Sig sebesar 0,078, sehingga dapat diambil kesimpulan hasil

TEKNO Vol. 28 Issue 2, p142-148 | Jurusan Teknik Elektro, Universitas Negeri Malang, Indonesia | September 2018 Ahmad L. Hidayatulloh, Tri Atmadji Sutikno, I Made Wirawan | Perbedaan hasil belajar dasar desain grafis dengan... 


\section{TEKNO Jurnal Teknologi Elektro dan Kejuruan}

http://journal2.um.ac.id/index.php/tekno | ISSN 1693-8739

yang diperoleh adalah homogen berdasarkan ketetapan jika signifikansi yang didapatkan lebih besar dari 0,05, maka hasil yang didapat adalah homogen.

2. Hasil uji homogenitas kemampuan akhir kelas eksperimen dan kelas kontrol didapatkan hasil signifikansi Asymp-Sig sebesar 0,645 untuk ranah kognitif dan 0,644 untuk ranah psikomotorik, sehingga dapat diambil kesimpulan hasil yang diperoleh adalah homogen berdasarkan ketetapan jika signifikansi yang didapatkan lebih besar dari 0,05, maka hasil yang didapat adalah homogen.

Setelah melakukan uji prasyarat analisis, maka dilakukan uji hipotesis. Uji hipotesis digunakan untuk mengetahui signifikansi akhir antara kelas eskperimen dan kelas kontrol. Pada uji hipotesis ini ditetapkan taraf signifikansi sebesar 0,05 sehingga pengambilan keputusan adalah sebagai berikut:

1. Nilai probabilitas $>0,05$ maka $\mathrm{HO}$ diterima $\mathrm{Ha}$ ditolak, yang berarti tidak terdapat perbedaan hasil belajar dasar desain grafis.

2. Nilai probabilitas $<0,05$ maka $\mathrm{HO}$ ditolak Ha diterima, yang berarti terdapat perbedaan hasil belajar dasar desain grafis.

Hasil dari uji hipotesis diuraikan sebagai berikut.

1. Pada kelas eksperimen didapatkan hasil signifikansi sebesar 0,03 , sehingga berdasarkan ketetapan yang telah diuraikan sebelumnya terdapat perbedaan hasil belajar dasar desain grafis.

2. Pada kelas kontrol didapatkan hasil signifikansi sebesar 0,04 , sehingga berdasarkan ketetapan yang telah diuraikan sebelumnya terdapat perbedaan hasil belajar dasar desain grafis

\section{Kesimpulan}

Berdasarkan hasil penelitian dan pembahasan yang diuraikan sebelumnya, maka dapat diambil kesimpulan sebagai berikut:

1. Terdapat peningkatan hasil belajar dasar desain grafis dengan menggunakan model pembelajaran CBL (Challenge Based Learning) berbantuan animasi pada siswa kelas $\mathrm{X}$ di SMK Islam Batu. Peningkatan ini diketahui dengan cara membandingkan nilai kemampuan awal siswa (pre-test) dengan kemampuan akhit siswa (post-test) setelah siswa diberikan perlakuan.

2. Terdapat peningkatan hasil belajar dasar desain grafis dengan menggunakan model pembelajaran CBL (Challenge Based Learning) berbantuan web pada siswa kelas $\mathrm{X}$ di SMK Islam Batu. Peningkatan ini diketahui dengan cara membandingkan nilai kemampuan awal siswa (pre-test) dengan kemampuan akhit siswa (post-test) setelah siswa diberikan perlakuan.

3. Terdapat perbedaan hasil belajar dasar desain grafis dengan menerapkan model pembelajaran CBL berbantuan animasi dibandingkan dengan model pembelajaran CBL berbantuan web untuk ranah kognitif pada siswa kelas eksperimen dan kontrol di SMK 


\section{TEKNO Jurnal Teknologi Elektro dan Kejuruan}

http://journal2.um.ac.id/index.php/tekno | ISSN 1693-8739

Islam Batu. Perbedaan tersebut dapat dilihat dari hasil belajar serta signifikansi uji hipotesis yang didapatkan.

4. Terdapat perbedaan hasil belajar dasar desain grafis dengan menerapkan model pembelajaran CBL berbantuan animasi dibandingkan dengan model pembelajaran CBL berbantuan web untuk ranah psikomotorik pada siswa kelas eksperimen dan kontrol di SMK Islam Batu. Perbedaan tersebut dapat dilihat dari hasil belajar serta signifikansi uji hipotesis yang didapatkan.

Berdasarkan pembahasan dan kesimpulan yang telah dikemukakan, maka peneliti menyarankan hal-hal berikut :

1. Bagi Guru

Melalui hasil penelitian ini, untuk kedepannya guru diharapkan dapat meningkatkan hasil belajar baik dari ranah kognitifnya maupun ranah psikomotoriknya. Diharapkan pula, guru mampu menguasai model pembelajaran yang digunakan supaya penerapannya di pembelajaran menjadi lebih kondusif atau lebih tenang. Media yang digunakan pun diharapkan kedepannya lebih diperhatikan, guna mendapatkan media yang menarik serta sesuai dengan karakteristik siswa sehingga siswa tidak cenderung pasif saat pembelajaran.

2. Bagi Siswa

Melalui penelitian ini, diharapkan siswa dapat lebih meningkatkan hasil belajarnya serta terus mengasah keterampilannya. Siswa juga diharapkan untuk merangkum materi yang telah diberikan supaya tidak mudah lupa materi tersebut, selain itu perlu dilakukan latihan-latihan keterampilan untuk meningkatkan keterampilannya

3. Bagi Peneliti Selanjutnya

Pada penelitian selanjutnya, diharapkan dapat mengembangkan media pembelajaran yang lebih baik lagi serta bermanfaat bagi sekolah agar nantinya dapat menunjang proses belajar yang berimbas pada peningkatan mutu pendidikan. Penelitian lebih lanjut diperlukan khususnya terhadap faktor-faktor lain yang memengaruhi hasil belajar seperti gaya belajar, model pembelajaran yang berbeda, kemampuan berpikir kritis, pemahaman konsep dan sebagainya yang tidak dibahas pada penelitian ini.

\section{Daftar Rujukan}

Johnson, dkk. 2009. Challenge-Based Learning: An Approach for Our Time. Austin, Texas: The

New Media Consortium. (online) (http://cbl.digitalpromise.org/wpcontent/uploads/sites/7/2016/06/Challenge-Based_Learning-

An_Approach_for_Our_Time.pdf) diakses pada tanggal 20 Maret 2018Majid, A. 2013. Perencanaan Pembelajaran. Bandung: Rosda Karya.

Majid, A. 2015. Penilaian Autentik Proses dan Hasil Belajar. Bandung: PT Remaja Rosdakarya. Sadiman. 2010. Media Pembelajaran. Jakarta: PT. Rajawali Press. 
TEKNO Jurnal Teknologi Elektro dan Kejuruan

http://journal2.um.ac.id/index.php/tekno | ISSN 1693-8739

Yudo, dkk. 2013. Pengaruh Penerapan Challenge Based Learning Terhadap Aktifitas dan Hasil Belajar Matematika Pada Siswa Kelas VII SMP Negeri 09 Salatiga. (online) (http://repository.uksw.edu/bitstream/123456789/4970/3/T1_202010020_Fulltext.pdf) diakses 26 Maret 2018. 